\title{
Recanalization of a complete colorectal anastomotic stenosis: an application of the Hot AXIOS stent
}

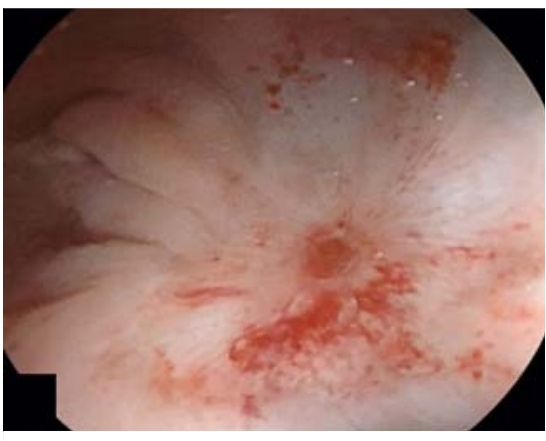

-Fig. 1 Endoscopic image showing complete obstruction of the colorectal anastomosis.

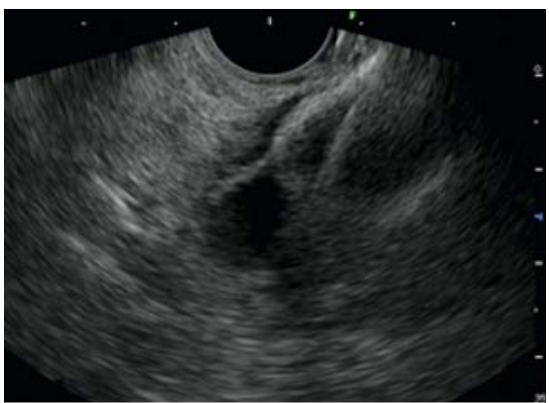

$\checkmark$ Fig. 2 Endoscopic ultrasound image showing the distal anchor flange of the lumen-apposing metal stent being released.

A 43-year-old woman underwent emergency surgery for a neoplastic colonic perforation. A sigmoidectomy with colorectal anastomosis protected by an ileostomy was performed. Pathological findings showed a well differentiated pt4N1aM0 adenocarcinoma. FOLFOX adjuvant chemotherapy was given. At endoscopy, 3 months later, a complete anastomotic stenosis was detected ( $\triangleright$ Fig. 1). After discussion with the surgical team, it was decided to proceed with endoscopic management using a lumenapposing metal stent (LAMS), as described in previous cases[1,2].

A therapeutic linear echoendoscope (EG580UT; Fujifilm, Tokyo, Japan) was positioned in the rectum. After the supraste-

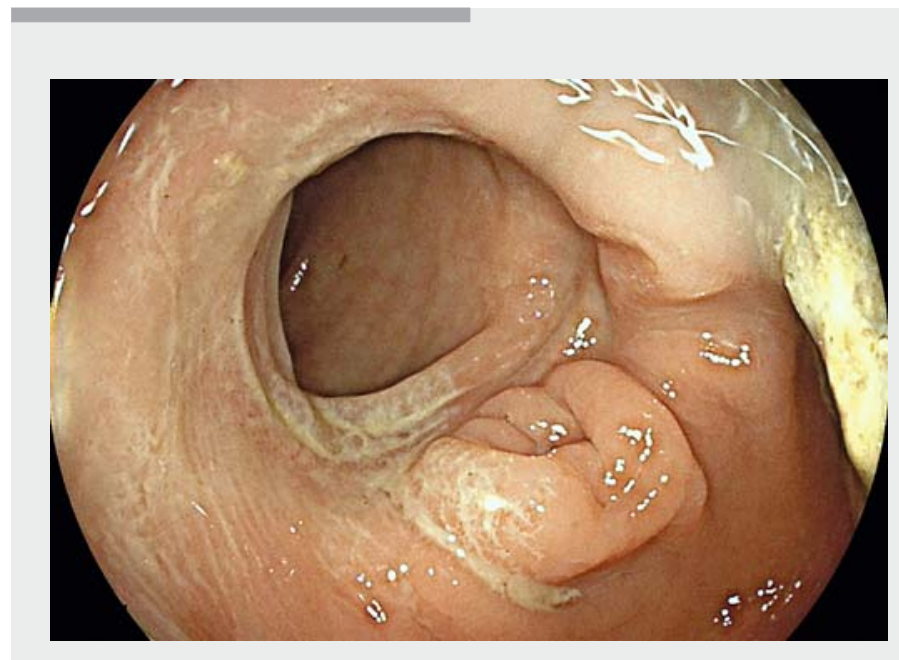

notic colon had been identified with the echoendoscope, a 19G needle (Boston Scientific Corp.) was inserted into the center of the stenosis. Opacification under fluoroscopic control confirmed the correct positioning of the needle and allowed the upstream colon to be filled. A 0.035-inch guidewire (Jagwire; Boston Scientific Corp.) was inserted into the left colon. A $15 \times 10-m m$ cautery-enhanced LAMS (Hot AXIOS; Boston Scientific Corp.) was deployed using pure cutting current, without any complications

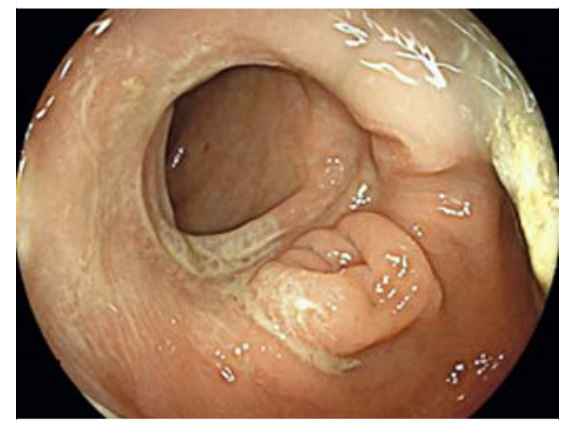

- Fig. 4 Image during a follow-up endoscopy 1 month after the lumen-apposing metal stent had been removed showing recanalization of the colon.

( Fig. 2 and $\triangleright$ Fig. 3). The stent was removed 1 month later with a grasper, leaving a large anastomosis. There was no recurrence of the stenosis on endoscopic follow-ups at 1 month ( $\mathbf{F i g . 4 )}$ and 1 year ( $\triangleright$ Video 1$)$.

This case demonstrates that a LAMS is also useful in postoperative benign strictures and may avoid the need for surgery.

Endoscopy_UCTN_Code_TTT_1AQ_2AF 
P. G. has a consultant relationship with Boston Scientific.

The authors

Jérôme Winkler, Charles Peyret, Marine Barraud-Blanc, Pablo Sage, Olivier Comiti, Laurent Heyries, Philippe Grandval

Department of Gastroenterology, Timone

University Hospital, Marseille, France

\section{Corresponding author}

Jérôme Winkler, MD

Department of Gastroenterology, Timone University Hospital, 278 Rue Saint-Pierre, 13005 Marseille, France

jerome.winkler@ap-hm.fr

\section{References}

[1] Gornals JB, Albines G, Trenti L et al. EUSguided recanalization of a complete rectal anastomotic stenosis by use of a lumen-apposing metal stent. Gastrointest Endosc 2015; 82: 752

[2] Nunes G, Marques PP, Patita M et al. EUSguided recanalization of complete colorectal anastomotic stenosis using a lumen-apposing metal stent. Endosc Ultrasound 2019; 8: 211-212

Bibliography

Endoscopy 2021; 53: E126-E127

DOI 10.1055/a-1215-9947

ISSN 0013-726X

published online 5.8.2020

(c) 2020. Thieme. All rights reserved.

Georg Thieme Verlag KG, Rüdigerstraße 14,

70469 Stuttgart, Germany
ENDOSCOPY E-VIDEOS

https://eref.thieme.de/e-videos

口回回 Endoscopy E-Videos is a free access online section, reporting 田: on interesting cases and new techniques in gastroenterological endoscopy. All papers include a high quality video and all contributions are freely accessible online.

This section has its own submission website at

https://mc.manuscriptcentral.com/e-videos 